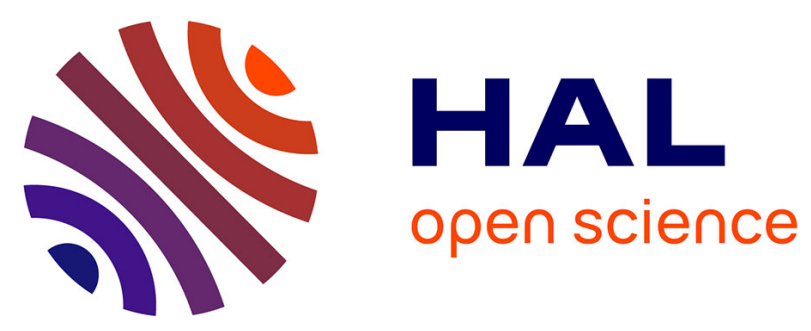

\title{
Vertical flow constructed wetlands subject to load variations : an improved design methodology connected to outlet quality objectives.
}

\author{
Catherine Boutin, S. Prost Boucle
}

\section{- To cite this version:}

Catherine Boutin, S. Prost Boucle. Vertical flow constructed wetlands subject to load variations: an improved design methodology connected to outlet quality objectives.. 14th IWA international conference on wetland systems for water pollution control (ICWS 2014), Oct 2014, Shanghai, China. pp.8. hal-02601664

\author{
HAL Id: hal-02601664 \\ https://hal.inrae.fr/hal-02601664
}

Submitted on 5 Jul 2021

HAL is a multi-disciplinary open access archive for the deposit and dissemination of scientific research documents, whether they are published or not. The documents may come from teaching and research institutions in France or abroad, or from public or private research centers.
L'archive ouverte pluridisciplinaire HAL, est destinée au dépôt et à la diffusion de documents scientifiques de niveau recherche, publiés ou non, émanant des établissements d'enseignement et de recherche français ou étrangers, des laboratoires publics ou privés. 


\title{
Vertical flow constructed wetlands subject to load variations: an improved design methodology connected to outlet quality objectives.
}

\author{
C. Boutin*and S. Prost-Boucle*. \\ *Irstea (ex-Cemagref), Research Unit: Freshwater Systems, Ecology and Pollution, 5, rue de la Doua \\ CS 70077 F-69626 Villeurbanne Cedex catherine.boutin@irstea.fr
}

\begin{abstract}
This study set out to assess how vertical flow constructed wetlands (vfCW) adapt to different types of tourism-driven variations in influent load, i.e. (i) campsites, closed for six months of the year and featuring a two-month-only window of high-season activity, and (ii) tourist-interest villages either hosting tourists over at least the six months of summer while the permanent population is resident or summer festivals that create intense pollution loads in a short burst of just a few days.

The study surveyed 4 campsites and 4 tourist-interest villages that were monitored for several years, generating over 70 performance balances for vfCW that were intentionally scaled down in relation to the conventional French design for experimental trials.

The influent wastewater effectively qualifies as domestic sewage, although relatively concentrated, with the campsites presenting particularly high nitrogen concentrations (122 gTKN.L $\left.{ }^{-1}\right)$.

The applied daily loads were also particularly high, with some combinations of load parameters (hydraulic load, organic matter, TKN) leading to $400 \%$ overloading.

Even under these drastic conditions, quality of effluent remained excellent on the characteristic organic matter parameters, with removal performances always over $85 \%$. However, nitrification performances were poor to good. Analysis of the dataset points to two major design thresholds:

For campsites, in order to keep a $73 \%$ nitrification rate even at the height of the summer season, the load applied to the $1^{\text {st }}$ stage filter in operation has to be capped at less than $600 \mathrm{gCOD} \cdot \mathrm{m}^{-2} \cdot \mathrm{d}^{-1}$.

For tourist-interest villages, in order to keep an $85 \%$ nitrification rate in the summer season, the load applied to the $2^{\text {nd }}$ stage filter in operation has to be capped at less than $22 \mathrm{gTKN} \cdot \mathrm{m}^{-2} \cdot \mathrm{d}^{-1}$.

Here, vfCW were demonstrated to robustly handle a massive increase in loads applied, providing the wetland construction and operation stringently follow best design standards and practices.
\end{abstract}

Key words: applied loads, design, fluctuations, nitrogen, vertical flow Constructed Wetlands

\section{INTRODUCTION}

Tourism is a major driver of the French economy, with tourism consumption-up 3\% between 2011 and 2012 - put at an estimated $€ 149$ billion in 2012 (Ministère en charge du tourisme, 2013). France pulls tourists in across the whole country, even if the distribution is uneven, with tourists gravitating towards the zones lining the Mediterranean and Atlantic coastline zones and the mountain-upland regions. The net result is that rural-sector tourism is outstandingly-well catered for, with 2,713.7 thousand beds on campsites (reflecting the ruralzone-specific accommodation offer) accounting for almost half (47.2\%) of global accommodation offer across France.

Friendly weather thus brings the additional influx of a seasonal population that needs to be provided with appropriately-scaled infrastructure amenities (potable water, wastewater treatment, transport links, and so on) — whether by publicly-authority organizations (including tourist-interest villages) or private-sector host facilities such as campsites and holiday parks.

Campsites stand out by their extreme seasonality. The general pattern is two-month-only window of high-season activity, with amenities closed to the public in winter. For touristinterest villages, the situation is less clear-cut-the tourist season is longer, and there is a permanent population resident all year round. Simple economics dictates that (to avoid scaling up infrastructure based exclusively on peak affluence activity) amenities should ideally be optimally scaled while continuing to meet both variable needs and any regulatory targets set. 
To address the issue, experimental trials in France have installed several vertical flow Constructed Wetlands (vfCW) scaled at a variety of sizes. The vfCW treatment solution offers a number of advantages: the technology is accessible, robust and reliable, and the signs suggest it can appropriately adapt to tourism-driven variations in influent load (Kadlec et al., 2008). In an equivalent approach, trials have been led in Italy in several types of CWincluding one vfCW-preceded by a primary settlement (Masi et al., 2007). The 8 vfCW studied here were designed to conventional French construction basis and are fed with raw wastewater that has simply been screened. The filters are batch-fed in doses to ensure optimal water and TSS distribution and improve oxygen supply. This configuration is known to enable good degradation of organics, good capture of TSS, and practically full nitrification (Boutin et al., 1997; Molle et al., 2005).

After a brief description of the influent wastewater tackled, this paper reports our in-depth analysis of running conditions for these 8 experimental vfCW. The analysis emerges a definition of the acceptable influent load thresholds on each stage according to the effluent quality objectives targeted. We conclude by proposing a specific design scale adapted the various situations of summer-season pollutant load variation.

\section{MATERIAL \& METHODS}

The dataset comes from $8 \mathrm{vfCW}$ receiving wastewater of 4 campsites and 4 tourist-interest villages.

The campsites have a several-hectare area and are rated 'deluxe/luxury' according to the classification scheme proposed under the opposite French legislation dated 11 January 1993.

The tourist zones studied are in rural-area settings where peak populations remain modest, at up to 1500 inhabitants for the two tourist-interest villages. Population can double or quadruple in summer depending on local setting. A very high coefficient of high-season/off-season swing is explained by a village that counts 290 permanent residents but hosts a summer festival, whereas a modestly-sized public campsite connected to the sewerage network will bring a much lower population swing (see Table 1).

The area of all $8 \mathrm{vfCW}$ is reported in Table 1 . Seven sites were intentionally down-scaled in relation to classic values-with six sites down-scaled by over half. All other key implementation factors (material, ventilation pipes, batch-fed dosing, etc.) remain unchanged. The measurement campaigns spanned several years, starting as soon as the amenities were opened to the public in 2007 and running through to 2013 for the campsites. The vast majority of measurements were naturally taken in high tourist season, but a fraction (10\%-20\% of the performance balances depending on measurement point) were taken off-season, i.e. in midJune and late-August for the campsites and in winter for the tourist-interest villages. The bulk of the measurements came from site 1 , site 2 and site A. To integrate the uneven split in number of performance balances available per site, the values cited are, where appropriate, weighted averages corrected for site-count.

All data processed are measured from 24-hr performance balances, generally reconstructed samples proportional to flow rate. The final dataset ultimately features 25 performance balances co-characterizing raw wastewater influent, output from the $1^{\text {st }}$ stage of the vfCW, and effluent, 33 performance balances co-characterizing influent raw wastewater and effluent, and 17 performance balances characterizing effluent only.

Special focus was paid to the raw wastewater samples, which posed real challenges to sample collection at the campsites where there was no pre-treatment of pollutant load transiting 
through a short-loop network. To resolve this issue, we opted to re-position the sampling strainer and to synchronize samplings at each batch-feed.

Each treatment stage was assessed against the parameters COD, BOD 5 , TSS, TKN, N-NH${ }_{4}^{+}$, $\mathrm{N}_{-} \mathrm{NO}_{3}{ }^{-}, \mathrm{TP}$ and $\mathrm{P}-\mathrm{PO}_{4}{ }^{3-}$ in line with standardized methods (AFNOR, 2008).

Table 1 Descriptive data on the 8 tourist facility activities and their corresponding 8 vfCW

\begin{tabular}{|c|c|c|c|c|c|c|c|c|}
\hline \multicolumn{5}{|c|}{ Campsites } & Site 1 & Site 2 & Site 3 & Site 4 \\
\hline \multicolumn{4}{|c|}{ Classification / grade } & stars & 4 & 4 & 3 & 4 \\
\hline \multirow{2}{*}{\multicolumn{3}{|c|}{ Pitch allocation }} & & mobile homes & 40 & 160 & 40 & 94 \\
\hline & & & & tents & 160 & 0 & 60 & 157 \\
\hline \multicolumn{4}{|c|}{ Total area } & hectares & 7 & 10 & 8 & 4 \\
\hline \multicolumn{4}{|c|}{ Host capacity } & campers & 900 & 800 & 400 & 1000 \\
\hline \multirow{2}{*}{\multicolumn{3}{|c|}{ total area }} & & $\mathrm{m}^{2}$ & 744 & 651 & 755 & 1044 \\
\hline & & & & $\mathrm{m}^{2} /$ camper & 0.83 & 0.81 & 2.02 & 1.04 \\
\hline \multirow{6}{*}{$\underbrace{3}_{i}$} & \multirow{3}{*}{\multicolumn{2}{|c|}{$1^{\text {st }}$ stage }} & number of $\mathrm{f}$ & lters & 3 & 3 & 3 & 3 \\
\hline & & & & $\mathrm{m}^{2}$ & 474 & 456 & 453 & 612 \\
\hline & & & total area & $\mathrm{m}^{2} /$ camper & 0.53 & 0.57 & 1.21 & 0.61 \\
\hline & \multirow{3}{*}{\multicolumn{2}{|c|}{$2^{\text {nd }}$ stage }} & number of $\mathrm{f}$ & lters & 3 & 3 & 2 & 3 \\
\hline & & & & $\mathrm{m}^{2}$ & 270 & 195 & 302 & 432 \\
\hline & & & total area & $\mathrm{m}^{2} /$ camper & 0.30 & 0.24 & 0.81 & 0.43 \\
\hline \multicolumn{5}{|c|}{ Tourist-interest villages } & Site A & Site B & Site D & Site E \\
\hline \multicolumn{5}{|c|}{ Tourist activity category } & heritag & village & $\begin{array}{c}\text { festival once/year, } \\
\text { lasting } 1 \text { week }\end{array}$ & $\begin{array}{l}\text { village with } \\
\text { campsite }\end{array}$ \\
\hline \multirow{2}{*}{\multicolumn{2}{|c|}{ Population }} & & wintertime & inhabitants & 555 & 420 & 290 & 350 \\
\hline & & & mer peak & inhabitants & 1552 & 1500 & 5000 & 500 \\
\hline \multicolumn{5}{|c|}{ Coefficient of high-season/off-season swing } & 2.8 & 3.6 & 17.2 & 1.4 \\
\hline \multirow{8}{*}{$\underbrace{3}_{i}$} & \multirow{2}{*}{\multicolumn{2}{|c|}{ total area }} & & $\mathrm{m}^{2}$ & 1550 & 738 & 1830 & 720 \\
\hline & & & & $\mathrm{m}^{2} /$ inhab. $\max$ & 1.00 & 0.49 & 0.37 & 1.44 \\
\hline & \multirow{3}{*}{\multicolumn{2}{|c|}{$1^{\text {st }}$ stage }} & number of $\mathrm{f}$ & lters & 3 & 3 & 4 & 3 \\
\hline & & & \multirow{2}{*}{ total area } & $\mathrm{m}^{2}$ & 1050 & 432 & 1200 & 432 \\
\hline & & & & $\mathrm{m}^{2} /$ inhab. $\max$ & 0.68 & 0.29 & 0.24 & 0.86 \\
\hline & \multirow{3}{*}{\multicolumn{2}{|c|}{$2^{\text {nd }}$ stage }} & number of $\mathrm{f}$ & lters & 2 & 2 & 2 & 2 \\
\hline & & & \multirow{2}{*}{ total area } & $\mathrm{m}^{2}$ & 500 & 306 & 630 & 288 \\
\hline & & & & $\mathrm{m}^{2} /$ inhab. max & 0.32 & 0.20 & 0.13 & 0.58 \\
\hline
\end{tabular}

\section{RESULTS \& DISCUSSION}

\section{Quality of domestic wastewater}

Wastewater pollutant concentrations were relatively homogeneous depending on campsite (see Table 2). The drinking water-saving recycling systems at certain sites led to higher pollutant concentrations on all parameters across the board. The mean values of the characteristic organic matter parameters remained consistent with earlier results (Boutin et al., 2010) and depict a typically-concentrated effluent transiting through a short-loop network. However, the wastewater was nevertheless nitrogen-packed (mean of $122 \mathrm{mgTKN}^{-1}{ }^{-1}$ ) at almost double normal concentrations. People camping tend to make basic meals that thus generate less domestic wastewater-therefore leading to a lower organic matter fraction in relation to nitrogen that is mainly vectored in via urine.

In tourist-interest villages, in high summer season, mean effluent quality tends to be more pollutant-packed than a typical average domestic wastewater-at around 20\%-40\% more depending on parameter. In the winter season, the mean concentrations confirm that the influent is regular domestic wastewater. The range of variability is particularly high in winter: wastewater concentrations directly reflect responsible water use and type of network: combined/separate sewer system. 
Table 2. Quality of domestic wastewater discharges from in-season campsite activity and in rural tourist-interest villages

\begin{tabular}{|c|c|c|c|c|c|c|c|c|c|}
\hline & & \multicolumn{5}{|c|}{ Concentrations (mg.L $\left.\mathrm{L}^{-1}\right)$} & \multicolumn{2}{|c|}{ Ratios } \\
\hline & & & $\mathrm{BOD}_{5}$ & COD & TSS & TKN & $\mathrm{N}-\mathrm{NH}_{4}{ }^{+}$ & $\begin{array}{l}\text { TKN/ } \\
\text { COD }\end{array}$ & $\begin{array}{c}\mathrm{N}_{-\mathrm{NH}_{4}}^{+} \\
/ \mathrm{TKN}\end{array}$ \\
\hline \multirow{3}{*}{\multicolumn{2}{|c|}{ Campsites }} & $\begin{array}{l}\text { weighted mean } \\
4 \text { sites }\end{array}$ & 367 & 915 & 432 & 122 & 99 & 0.14 & 0.80 \\
\hline & & \multirow{2}{*}{$\begin{array}{l}33-34 \\
\text { data }\end{array}$} & 680 & 1400 & 740 & 170 & 150 & 0.19 & 0.94 \\
\hline & & & 220 & 529 & 160 & 79 & 51 & 0.09 & 0.62 \\
\hline \multirow{6}{*}{ 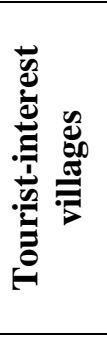 } & \multirow{3}{*}{ summer } & $\begin{array}{c}\text { weighted mean } \\
3 \text { sites }\end{array}$ & 378 & 792 & 311 & 90 & 71 & 0.13 & 0.86 \\
\hline & & Max. $12-19$ & 704 & 1298 & 571 & 113 & 85 & 0.20 & 1.97 \\
\hline & & Min. data & 190 & 476 & 160 & 25 & 38 & 0.07 & 0.67 \\
\hline & \multirow{3}{*}{ winter } & $\begin{array}{c}\text { weighted mean } \\
3 \text { sites }\end{array}$ & 320 & 647 & 302 & 60 & 43 & 0.10 & 0.76 \\
\hline & & Max. $\quad 6-7$ & 1102 & 1677 & 1072 & 119 & 68 & 0.12 & 0.89 \\
\hline & & Min. & 45 & 105 & 35 & 13 & 11 & 0.07 & 0.57 \\
\hline \multirow{3}{*}{\multicolumn{2}{|c|}{$\begin{array}{l}\text { Values for rural-area } \\
\text { settings } \\
\text { (Mercoiret, L., 2010) }\end{array}$}} & -area & 265 & 646 & 288 & 67 & 55 & 0.12 & 0.74 \\
\hline & & Max. & 570 & 1341 & 696 & 123 & 98 & 0.18 & 0.97 \\
\hline & & 10) & 39 & 122 & 53 & 14 & 12 & 0.063 & 0.50 \\
\hline
\end{tabular}

\section{All-round efficiency of the 8 vfCW}

\section{Quality of effluents}

Quality of effluents (see Table 3) appears globally better from tourist-interest villages than from campsites, even if the weighted means across sites in both settings qualify as excellent when benchmarked in terms of the regulatory thresholds (Council Directive 91/271/EEC of 21 May 1991).

Looking at total nitrogen, the results on indicators of nitrification are fairly scattered (see Figure 2a).

Table 3. Quality of effluents (mg. $\left.\mathrm{L}^{-1}\right)$ and removal performances $(\%)$ of the $8 \mathrm{vfCW}$ surveyed

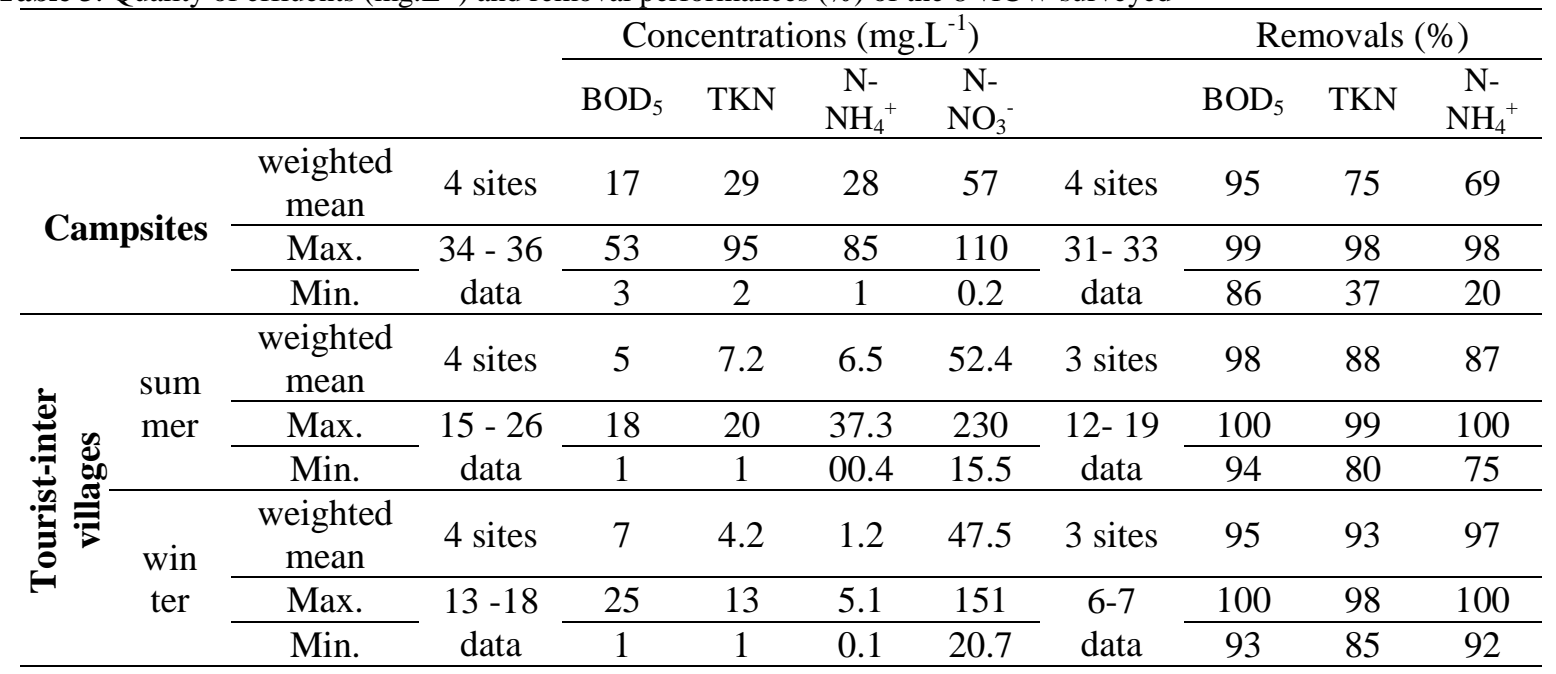

For campsites, the site sample size-weighted mean effluent remains TKN-heavy $\left(29 \mathrm{mg} . \mathrm{L}^{-1}\right)$ consistently with the high initial concentration of the raw wastewater. All organic nitrogen content gets fully oxidized. Nitrates production is variable (averaging $57 \mathrm{mg} \mathrm{N}-\mathrm{NO}_{3}{ }^{-} \mathrm{L}^{-1}$ but peaking at over $110 \mathrm{mg} \mathrm{N}-\mathrm{NO}_{3}{ }^{-} \cdot \mathrm{L}^{-1}$ ). Certain concentrations are near-zero, flagging a limit that typically signals impending anoxia and that can be used to define the threshold for particular operating conditions imposed on intentionally down-scaled vfCW. 
The tourist-interest villages post excellent effluent concentrations that never go over 20 mgTKN.L ${ }^{-1}$.

\section{Removal performances}

Treatment efficiency in terms of characteristic organic matter parameters is demonstrated by the fact that removal performances were systematically over $86 \%$ for BOD5 (see Table 3 ).

Looking at the total nitrogen parameters, for tourist-interest villages, the systematically $80 \%$ plus removal performances fit with expectations (Molle et al., 2005). For campsites, the mean removal performances of $75 \%$ for total Kjeldahl nitrogen and $69 \%$ for ammoniacal nitrogen very nearly fit with expectations, although the range of variability on both these parameters underscores how nitrogen is the critical factor shaping vfCW performances.

This survey highlights (i) good, solid, stable results on ability to degrade organic matter, and (ii) that degree of nitrification is the critical factor shaping vfCW performances.

In order to propose productive ways to improve nitrification, we led a finer-grained stage-bystage analysis. We cross-compared the various situations studied were (see Table 1) based on comparing real-world daily surface-dose loads applied against the conventional scaling rules (see Table 4) for a total vfCW surface of $2 \mathrm{~m}^{2}$.inhab ${ }^{-1}$ in two stages.

Table 4. Conventional criteria for French vfCW

\begin{tabular}{|c|c|c|c|c|c|c|c|}
\hline \multirow{4}{*}{$\begin{array}{c}\text { conventio } \\
\text { nal } \\
\text { criteria }\end{array}$} & \multicolumn{2}{|c|}{ surface area } & \multicolumn{3}{|c|}{ load applied on the filter in operation } & \multirow{2}{*}{\multicolumn{2}{|c|}{$\begin{array}{c}\text { expected remova } \\
\text { performances }\end{array}$}} \\
\hline & total & unitized & hydraulic & & & & \\
\hline & \multirow{2}{*}{\multicolumn{2}{|c|}{$\mathrm{m}^{2}$. inhab $^{-1}$}} & \multirow{2}{*}{$\mathrm{cm} \cdot \mathrm{d}^{-1}$} & \multicolumn{2}{|c|}{ g. $\mathrm{m}^{-2} \cdot \mathrm{d}^{-1}$} & \multicolumn{2}{|c|}{$\%$} \\
\hline & & & & COD & TKN & COD & TKN \\
\hline $1^{\text {st }}$ stage & 1.2 & 0.4 & 37.5 & 300 & $\approx 30$ & 79 & 56 \\
\hline $2^{\text {nd }}$ stage & 0.8 & 0.4 & 37.5 & 75 & 13.5 & 56 & 70 \\
\hline total & 2 & & & & & 90 & 86 \\
\hline
\end{tabular}

This design (Molle et al., 2005) is based on the pollutive once-daily effluent of one rural-area inhabitant, as evaluated by statistical analysis of 10,000 datapoints: 120 gCOD, 11.9 gTKN, $46 \mathrm{gBOD}_{5}$ and $150 \mathrm{~L}$ (Mercoiret L., 2010).

\section{Efficiency of the $1^{\text {st }}$ treatment stage of the $8 \mathrm{vfCW}$}

\section{Hydraulic load}

In high season, wastewater treatment plants tend to run at slight hydraulic underload: mean flush $\left(35.6 \mathrm{~cm} . \mathrm{d}^{-1}\right.$ for campsites and $27.3 \mathrm{~cm} \cdot \mathrm{d}^{-1}$ for tourist-interest sites) onto the $1^{\text {st }}$ stage filter in operation is close to conventional-design hydraulic loads $\left(37.5 \mathrm{~cm} . \mathrm{d}^{-1}\right)$. Note however that we did record a handful of extreme overload events that reached up to $175 \%$.

\section{Surface loads applied and removal performances}

The COD loads applied at tourist-interest villages and campsites were 2-fold-higher and 1.5fold-higher, respectively, than the design loads set under conventional conditions. Despite reaching 460-600 gCOD. $\mathrm{m}^{-2} \cdot \mathrm{d}^{-1}$, the organic matter content was treated reliably and relatively effectively given the regression coefficient (0.98) of the curve plotting daily surface-area loads applied $v s$ treated. The mean COD removal performances of this $1^{\text {st }}$ stage filter were $77 \%$ for campsites and $82 \%$ for tourist-interest villages.

TKN loads applied reached 75 gTKN.m ${ }^{-2} \cdot \mathrm{d}^{-1}$ for campsites and $37 \mathrm{gTKN} \cdot \mathrm{m}^{-2} \cdot \mathrm{d}^{-1}$ for touristinterest villages, which equates to substantial overloads ranging from $250 \%$ to $125 \%$ over the conventional value of $30 \mathrm{gTKN} \cdot \mathrm{m}^{-2} \cdot \mathrm{d}^{-1}$. 
Once over the 35-40 gTKN.m ${ }^{-2} \cdot \mathrm{d}^{-1}$ threshold, removal performances at campsites clearly start to drop away (see Figure 1a). Outside of these overload conditions, operational mistakes on certain sites_including over-slow dosing rates_explain certain mediocre results.
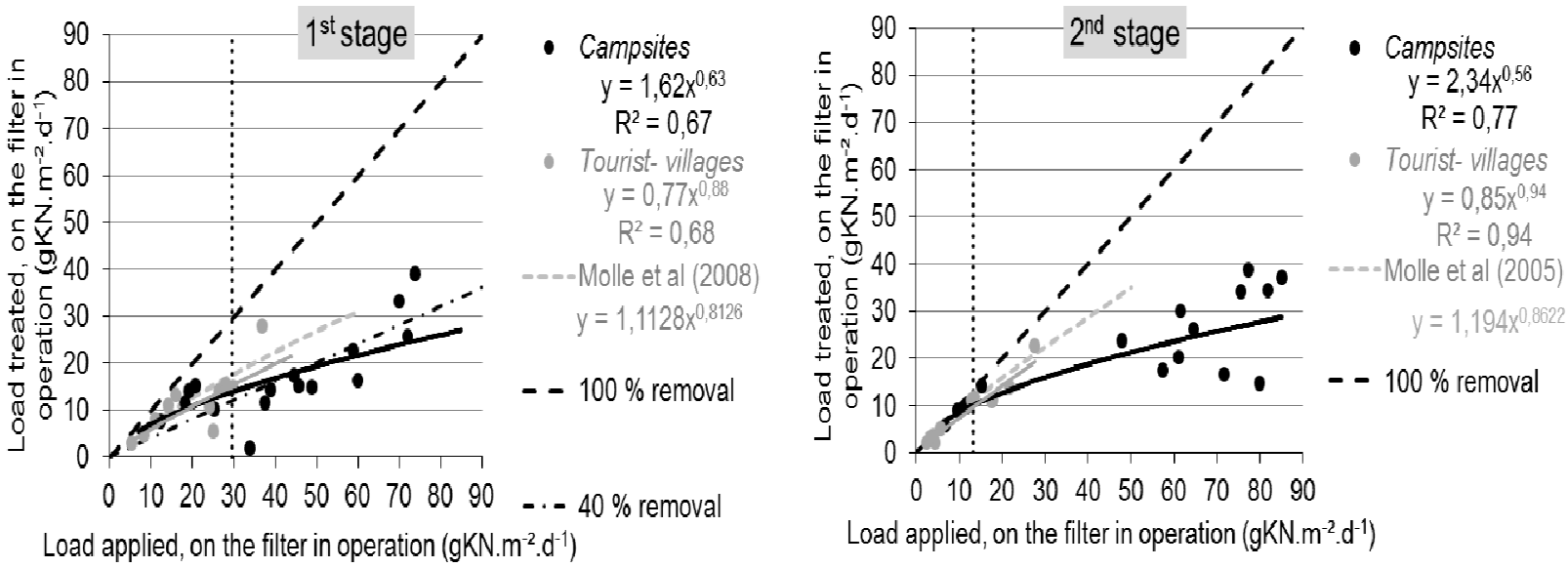

Figure 1 Efficiencies of the $1^{\text {st }}$ treatment stage (a) and the $2^{\text {nd }}$ treatment stage (b) on TKN

Even in these big load ranges, at least $75 \%$ of organic matter still gets removed. However, the lack of oxygen strangles the nitrification figure, which reaches $40 \%$ instead of a conventional $55 \%$ removal performance. These results are achievable inside the $1^{\text {st }}$ treatment stage provided the vfCW is designed, employed and maintained as per code of practice.

\section{Efficiency of the $2^{\text {nd }}$ treatment stage of the $8 \mathrm{vfCW}$}

Hydraulic load

In tourist-interest villages, even in high season, the diurnal hydraulic overloads remain modest (at around just $110 \%$ ). The design of the $2^{\text {nd }}$ stage at many campsite-based vfCW (see Table 1) that are equipped with 3 independent filters (rather than 2) explains the heavy hydraulic overloading (260\%) applied on the filter in feed-mode. A standard design would have led to mean overloads of around the $175 \%$ mark.

\section{Surface loads applied and removal performances}

The peak measured COD loads applied at tourist-interest villages and campsites were comfortably over the conventional design loads, i.e. 2.25-fold-higher at tourist-interest villages and 4-fold-higher at campsites. Nevertheless, treatment performances on organic matter were systematically at very respectable levels. Mean COD removal performance (58\%) was not just excellent but even matched the expectations set for conventional normal situations (Molle et al., 2005).

The TKN loads applied at tourist-interest villages and campsites were way over the conventional design loads (2.25-fold-higher at tourist-interest villages and 6.4-fold-higher at campsites, i.e. corresponding to peak values of $28-85 \mathrm{gTKN} \cdot \mathrm{m}^{-2} \cdot \mathrm{d}^{-1}$ for the filter in feed mode; see Figure 1). For tourist-interest villages, the removal performances still fit with expectations, in contrast with campsites, where nitrification first stalls at an applied load of 58 g TKN.m- ${ }^{2} \cdot \mathrm{d}^{-1}$.

Figure 2 also highlights how hydraulic loads applied on the in-feed-mode filter at the $2^{\text {nd }}$ stage impact negatively on nitrification performances. This negative impact is particularly visible at the many campsites working with a triple-filter design rather than the two-filter design. This is because excessive water input affects the ability of the matrix to reoxygenate and the oxygen content needed for nitrification. 
For implementation in line with standard-practice technical guidelines, by keeping hydraulic overload under $175 \%$, the regression line plotting flush input against nitrification performance $(y=-65.96 x+100)$ would put the predicted minimum nitrification threshold at $55 \%$.
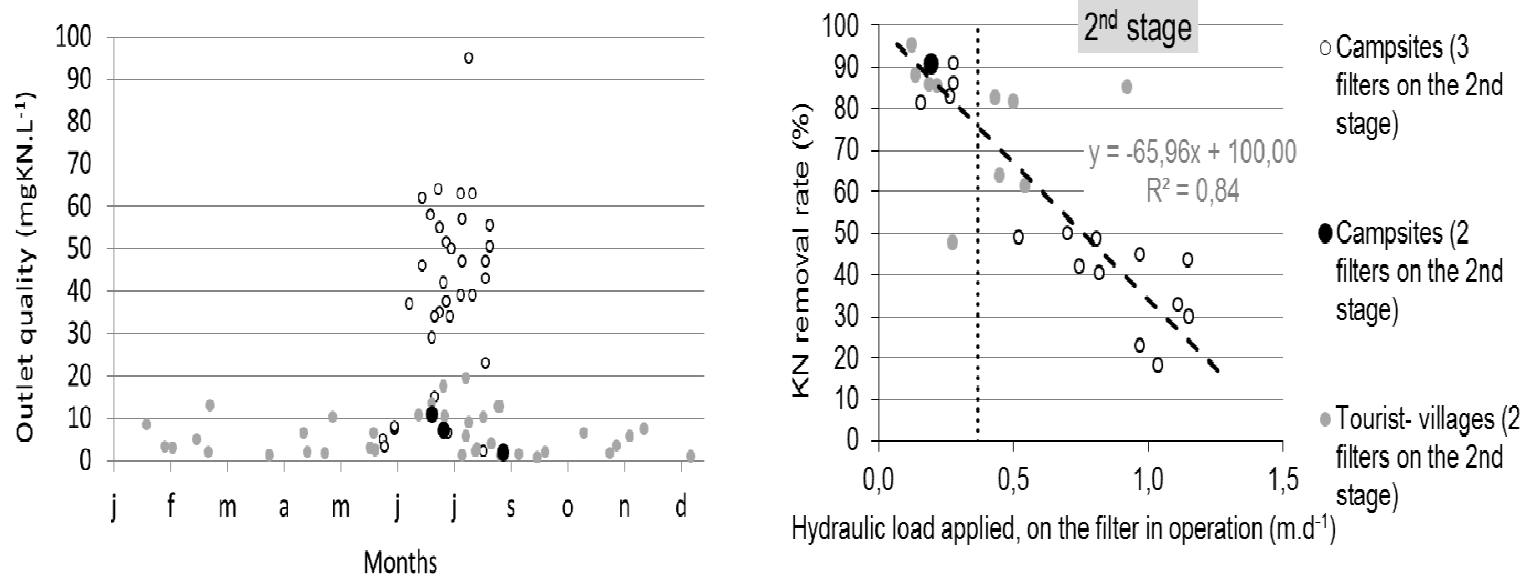

Figure 2: Season-stratified TKN concentrations of 74 effluents (a) and impact of hydraulic loads at the $2^{\text {nd }}$ treatment stage on nitrification (b)

\section{CONCLUSION}

Tourism is a major driver of the French economy. Simple economics dictates that amenities should ideally be optimally scaled while continuing to meet both variable needs and any regulatory targets set.

The study on 8 vfCW at 4 campsites and 4 tourist spots tracked over several years confirms the promise of this pollutant treatment solution as an appropriate technology in terms of robustness and ability to adapt to tourism-driven variations in influent load. However, appropriate and experienced design is absolutely fundamental to the success of these downscaled vfCW, making it vital to stick to the prescribed split in number of same-surface-area filters at each stage, i.e. 3 at the first stage and 2 at the second. Furthermore, vfCW will only deliver the expected performance results if they are run strictly in line with code of operational practice (including the filter dosing and resting intervals).

There are three situation profiles differentiated according to season and length of the peak pollution period.

\section{(i) Campsites}

Heavy overloads can be handled thanks to the absence of in-feed over the long winter season and subsequent virtually complete mineralization of vfCW surface deposits. While managing to maintain acceptable nitrification levels, at around $73 \%$ in peak periods, the limiting factor identified here is organic load applied on the in-feed-mode filter at the $1^{\text {st }}$ stage, which must not be allowed to go $200 \%$ over the basic conventional design level, i.e. 600 gCOD g.m ${ }^{-2} \cdot \mathrm{d}^{-1}$. These conclusions can be extrapolated up to any short-term pollutant discharges lasting less than three months if the system is allowed to stay completely pollution-free over the winter season. An analysis of the raw wastewater discharged by campers (Boutin et al., 2010) prompted the proposed design of $0.75 \mathrm{~m}^{2} /$ camper-a scale we can now confirm here.

(ii) Tourist-interest villages

Overloads can be handled thanks to the better conditions for summer-season organic matter degradation and mineralization. In relation to campsites, the viable handlable overloads are modulated by two key factors: (i) the fact that the tourist season is likely to be longer (spanning 5-6 months) and (ii) the fact that the vfCW receives pollution even during the offseason winter period. While managing to maintain nitrification performances at around $85 \%$, 
the limiting factor identified here is nitrogen load applied on $2^{\text {nd }}$ stage, which must not be allowed to go $160 \%$ over the basic conventional design level, i.e. 22 gTKN g.m $\mathrm{m}^{-2} \cdot \mathrm{d}^{-1}$.

To translate these findings into concrete real-world application, vfCW designers should evaluate the coefficient of high-season/off-season swing of the user population. If this coefficient is under 1.6, then the extra summer-season pollution can be absorbed without having to up-scale the wetland facility designed for winter-season treatment of pollution by a permanent resident population. If this coefficient is over 1.6, then vfCW design needs to be scaled against peak summer-season pollution load, but while allowing a $160 \%$ overload.

\section{(iii) Festivals}

The vfCW prove particularly robust if subjected to short-burst demand spanning very short periods (a few days up to a whole week). In this particular sub-setting, our proposal is to base vfCW design scale exclusively on the hydraulic load parameter and to assess operational performance based on the stage-by-stage organic and total nitrogen loads applied. These design parameters - provided the system is deployed to best design standards and practiceguarantee effective and dependable organic matter removal performances (88\%).

The level of the hydraulic and nitrogen loads applied has a direct impact on nitrification performances. Consequently, if local configuration requires stronger nitrification, it will be necessary to fall back on conventional scaling benchmarks. This point is by far the most critical design parameter when faced with heavily nitrogen-packed raw wastewater.

\section{ACKNOWLEDGEMENTS}

The authors warmly thank the many agencies and authorities that were involved in this study: Agence de l'Eau Adour-Garonne, Agence Régionale Pour l'Environnement, DEBAT [infrastructure design office], Conseil Régional Aquitaine, Office National de l'Eau et des Milieux Aquatiques, the owner-managers of the campsites surveyed, the Charente, Haute-Loire, Dordogne and Tarn département technical support services for wastewater treatment plant operators, and the Dordogne département Syndicat Départemental de l'Hôtellerie de Plein Air.

\section{REFERENCES}

AFNOR (2008). Qualité de l'Eau. ISBN: 978-2-12-179081-7.

Arrêté du 11 janvier 1993 relatif au classement des terrains aménagés pour l'accueil des campeurs et des caravanes. Journal Officiel du 13 janvier 1993, pp684-688

Boutin, C., Bois, J-S., Bouvard, V., Cadic G., Dodane, P.H., Iwema, A., Lapauze, P., Lesavre, J., Pigneur, Y., Savoye, D., Thoumy, D. (2007) Cadre guide pour un Cahier des Clauses Techniques Particulières (CCTP) Filtres Plantés de Roseaux, Ministère de l'Agriculture, CGGAER/ Pôle d'Appui Technique, Avril 2007, p76.

Boutin, C., Liénard, A. and Esser, D. (1997). Development of a new generation of reed-bed filters in France: First results. Water Sci. Technol. 35 (5), pp 315-322.

Boutin, C., Prost-Boucle, S., and Boucher, M. (2010). Robustness of vertical Reed Bed Filters facing loads variations: the particular case of campsites. Preprints 12th IWA International Conference, Wetland Systems for Water Pollution Control, Venice, Italy; Oct 4-8 $8^{\text {th }} 2010$.

Directive du Conseil n ${ }^{\circ}$ 91/271/CEE du 21 mai 1991 relative au traitement des eaux urbaines résiduaires. Journal Officiel de la Communauté Européenne nº 135/40 du 30 mai 1991

Kadlec, R. and Wallace, S. 2008. Treatment Wetlands. $2^{\text {nd }}$ Edition CRC press, Boca Raton, Fl, USA

Masi, F., Martinuzzi, N., Bresciani, R., Giovannelli, L. and Conte, G. (2007) Tolerance to hydraulic an organic load fluctuations in constructed wetlands. Water Sci. Technol. 56 (3), 39-48.

Mercoiret, L (2010). Qualité des eaux usées domestiques produites par les petites collectivités. Application aux agglomérations d'assainissement inferieures à 2000 Equivalents Habitants. Rapport final ONEMA Cemagref. 50p + annexes

Ministère de l'artisanat, du commerce et du tourisme (2013). Key facts on tourism. 2013 Edition. 4p

Molle, P., Liénard, A., Boutin, C., Merlin, G., Iwema, A. (2005). How to treat raw sewage with constructed wetlands: an overview of the French systems. Water Sci. Technol. 51 (9), 11-21.

Molle, P., Prost-Boucle, S and Liénard, A (2008). Potential for total nitrogen removal by combining vertical flow and horizontal flow constructedwztlands: a full- scale experiment study. Ecological Engineering. 34 (2008), 23-29. 